\title{
Multiplying embryos: experimental monozygotic polyembryony in mammals and its uses
}

\author{
ELLEN CASSER, STEFFEN ISRAEL and MICHELE BOIANI* \\ Max Planck Institute for Molecular Biomedicine, Muenster, Germany
}

\begin{abstract}
Monozygotic (MZ) polyembryony is a strategy to increase the output of a single zygote, thereby producing more offspring from a limited number of oocytes. However, MZ twins and multiples (multiplets) of mammals occur rarely in nature, while their generation has been more successful experimentally. In this work, we review some of the methodological, biological and field aspects of experimental $\mathrm{MZ}$ polyembryony in mammals. First attempts of mechanical bisection of 2-cell stage rodent embryos provided a proof-of-principle for the survival and independent development of both blastomeres. Subsequently, experiments in other species, particularly sheep and bovine, allowed 2 methods of embryo multiplication to become routine: the separation or biopsy of blastomeres from cleavage-stage embryos and the bisection of morulae and blastocysts. We discuss how the preferable stage of bisection and the success rate can be species-specific. The scope that profited most from experimental MZ polyembryony is the production of additional copies of elite livestock individuals, the reduction of interindividual variation in test groups and the possibility of investigating discordant phenotypic traits in the same genomic background, for instance, comparing an affected twin with its healthy co-twin. By contrast, the original motivation for experimental polyembryony - efficiently generating more offspring out of the same zygote - has not been fulfilled yet. Although embryo splitting leads to an increase in quantity, there is a loss of embryo quality, thus, there is no real gain from artificially generated embryos (yet) in the field of medically assisted reproduction. In conclusion, mammalian zygotes have the regulative capacity to be polyembryonic, but this is not obligate.
\end{abstract}

KEY WORDS: bisection, blastomere, mammal, polyembryony, zygote

\section{Introduction}

The concurrent birth of several offspring from the same mother is referred to as the birth of multiples (further referred to as multiplets). These multiplets can result from 2 scenarios: Either from the ovulation of more than one oocyte resulting in dizygotic (DZ) multiplets, or from the separation of a single embryo in an early developmental stage, forming 2 or more embryos (polyembryony) derived from one zygote, also known as monozygotic (MZ) multiplets. In a dizygotic pregnancy, each twin is nurtured by its own placenta, the chorion, and develops in its own amniotic sack, therefore, they are called dichorionic diamniotic. During early preimplantation development, the first blastomeres of the embryo are functionally independent from one another as long as gap junctions have not started to form, associated with flattening and compaction of cells at morula stage (Brison et al., 2014). As the number of blastomeres increases, the first cell fate decision results in an outer layer of future extraembryonic cells, the trophectoderm (TE), and an inner cell mass (ICM). Subsequently the ICM undergoes a second cell fate decision, differentiating into primitive endoderm (PE) and epiblast (EPI), giving rise to the expanded blastocyst - the last stage before implantation. Monozygotic twins generally share a chorion (monochorionic; Fig. 1). If the separation occurs at the blastocyst stage, by a separation of the ICM, the embryos will be diamniotic; if it happens after the embryo's implantation, they will be monoamniotic. If, in a very early stage, a separation of blastomeres occurs, even the twins of $\mathrm{MZ}$ pairs can develop their own placentae, resulting in a dichorionic pregnancy (Kyono, 2013). In vitro, $\mathrm{MZ}$ twins are artificially generated before implantation and

Abbreviations used in this paper: DZ, dizygotic; EPI, epiblast; ICM, inner cell mass; ICSI, intracytoplasmic sperm injection; MZ, monozygotic; PE, primitive endoderm; TE, trophectoderm; WOW, Well of the Well (culture system); ZP, zona pellucida.

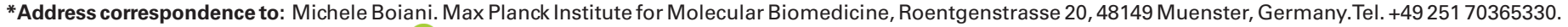
Email: mboiani@mpi-muenster.mpg.de - (iD https://orcid.org/0000-0003-2765-2781
} 

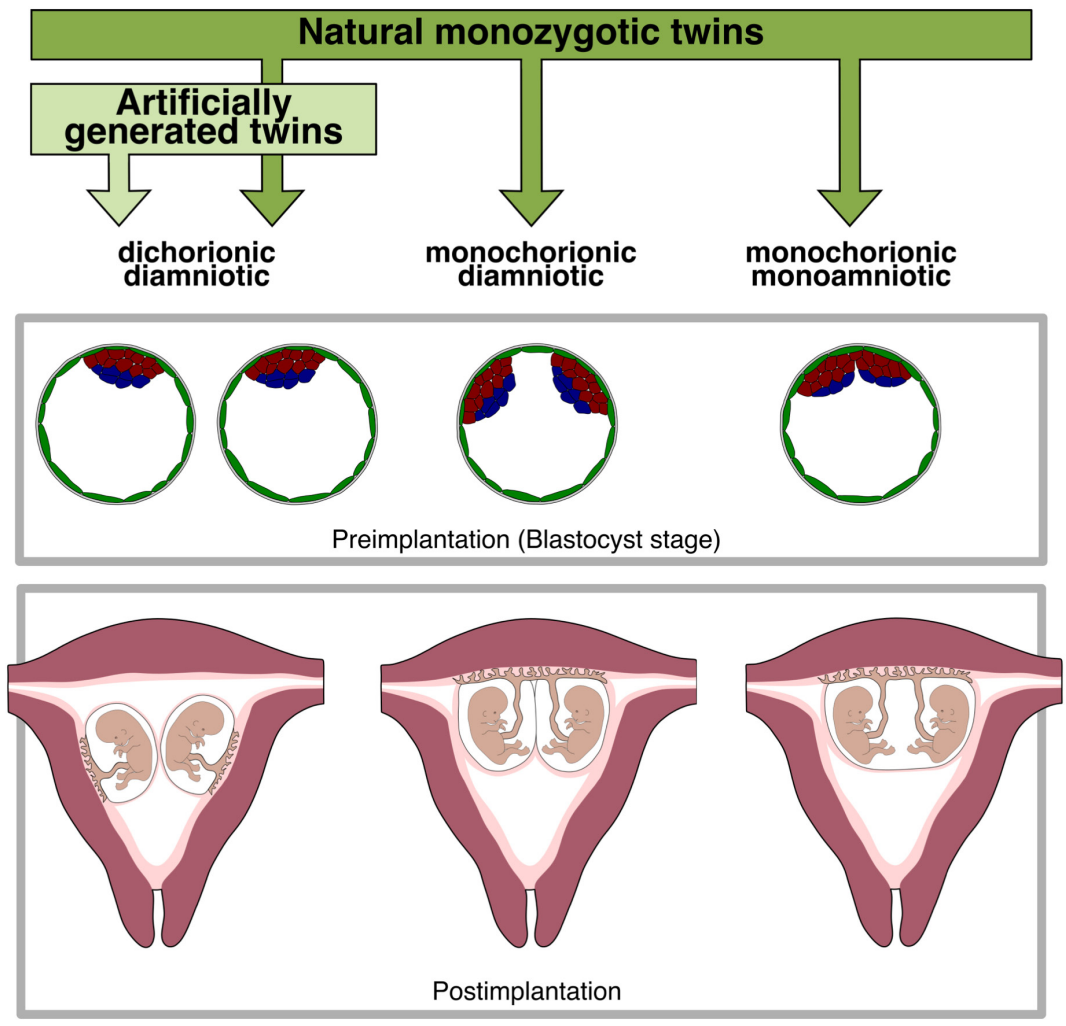

Fig. 1. Types of monozygotic twins and their reciprocal relationship within a schematic uterus. The earlier the separation of the cleavage-stage blastomeres or the inner cell mass (ICM, red and blue cells), the fewer extraembryonic tissues are shared by the twins arising. If the separation occurs in an early cleavage stage, so that the twins develop independently from one another and form their own trophectoderms (green cells) and ICMs, as they also do if the embryo is bisected experimentally, they develop their own chorion and amnion (dichorionic diamniotic). If the separation occurs in the stage of the blastocyst by a fission of the ICM, the twin embryos will share a placenta (monochorionic). Depending on the occurrence of separation at pre- or post-implantation, the twin embryos each have their own amniotic sack (diamniotic) or both share it (monoamniotic). generation may also represent a useful tool in animal breeding and biomedical research. The defining feature of $\mathrm{MZ}$ multiplets is their origin from one cell, a single fertilized oocyte, which means they are - at least at the beginning-genetically identical and, thus, 'clones' of one another. This congruence may change during development or later in postnatal life (Day et al., 2014; Wood and Trounson, 2000), but generally it remains true that most $\mathrm{MZ}$ twins are phenotypically very similar. This review of the literature aims to give an overview of what has been accomplished so far with artificially generated $\mathrm{MZ}$ twins and multiplets, and to illustrate the utility of this model to address commercial needs or biomedical questions. We learn from this review that the experimental model of polyembryony in mammals generally surpasses the natural polyembryony in terms of success rate, although the efficiency is not linearly proportional to the number of blastomeres. Accordingly, experimental polyembryony can be more advantageous for some purposes (e.g. creating copies of elite livestock, reducing the incidence of confounding factors in biomedical study designs) than it can be for others (e.g. increasing the efficiency of sexual reproduction). We also learn that, although the mouse is often the favorable species of choice in basic research, some of the most fundamental contributions to the experimental understanding of polyembryony were made in species other than the mouse.

\section{Prelude to monozygotic polyembryony: demi-embryos}

Before multiple embryos could be derived from one, investigators had to prove that a fraction of one embryo is viable. One of the first blastomere separation experiments in mammals was reported in 1942. Investigators tried to find a way to separate the blastomeres of 2-cell stage rat embryos. They removed cultured as individuals, thus, resulting in dichorionic diamniotic pregnancies after embryo transfer (Fig. 1).

Only one mammal, the nine-banded armadillo (Dasypus novemcinctus), is known to constantly produce $\mathrm{MZ}$ multiplets (Loughry et al., 1998), thereby limiting the variety of study models available. In other species, the less frequent natural occurrence of MZ twins was studied in cow (del Rio et al., 2006), pig (Bjerre et al., 2009) and chimpanzee (Ely et al., 2006), reported in sheep (Assheton, 1898; Rowson and Moor, 1964), horse (Govaere et al., 2009), dog (Joone et al., 2016) and even whales (Kimura, 1957), and presumed to be rare but extant in rabbit (Bomsel-Helmreich and Papiernik-Berkhauer, 1976) and mice (McLaren et al., 1995; Runner, 1984; Wallace and Williams, 1965). In humans, MZ twins are born in $0.3 \%$ of all spontaneous livebirths (Hall, 2003). After in vitro procedure and embryo transfer, the emergence of $\mathrm{MZ}$ twins is observed more frequently, as shown in species such as horse (Mancill et al., 2011; Roberts et al., 2015), cattle (Kraay et al., 1983; Niemann and Sacher, 1984) and human (Aston et al., 2008; Blickstein et al., 2003).

Natural MZ twins and multiplets are intriguing in their biogenesis, which has not yet been fully understood, and their artificial the zona pellucida (ZP), the protective extracellular coat of the embryo, by dissolution in an acidified Ringer solution and bisected the 2-cell stage blastomeres by either cutting, using a filigree glass needle or eye lash, or separating them by the pressure of a flow of fluid. These bisections resulted in isolated blastomeres that were still able to form egg-cylinder stage embryos (Nicholas and Hall, 1942). Similar experiments were also performed in rabbit (Seidel, 1952,1960) and in mice (Tarkowski, 1959a,b) by destroying one of the blastomeres of 2-cell stage embryos to investigate the developmental potential of the remaining blastomere (demi-embryo), which yielded live-born animals. Pioneering studies, such as those outlined above, paved the way for studies in which all blastomeres from the same embryo could be preserved for further investigation.

\section{Techniques available to induce monozygotic polyembryony}

Two different methods of embryo bisection are commonly used: The separation or biopsy of blastomeres in 2- to 8-cell stage embryos (Fig. 2A) and the bisection of the morula or blastocyst by surgical cutting (Fig. 2B). Nowadays, the separation of blasto- 
Fig. 2. Methods of embryo bisection. During the chemical blastomere separation procedure, a disaggregation of blastomeres is caused by the application of trypsin after the zona pellucida (ZP) has been dissolved by acidified Tyrode's solution or pronase (A, top). The mechanical separation is performed with the help of a micromanipulator (A, middle). Both techniques can also be combined by a chemical removal of the ZP and gentle pipetting to separate the blastomeres. A biopsy of individual blastomeres is performed using an aspirating pipette that is inserted through an opening in the ZP (A, bottom). During the bisection of morulae and blastocysts, the embryo is cut into 2 halves of approximately equal sizes by a sharp needle or microblade (B). Equal cell numbers in the ICM of both halves are especially important at the blastocysts stage.

meres is carried out either chemically by the use of trypsin solution after the ZP has been dissolved by acidified Tyrode's solution or pronase (Biase et al., 2014; Deng et al., 2014), or mechanically by a micromanipulator (Casser et al., 2017; Katayama et al., 2010; Roberts et al., 2011; Sotomaru et al., 1998), or by a combination of both, i.e. the ZP is removed chemically and the blastomeres are separated by gentle pipetting (Goolam et al., 2016; Hashiyada et al., 2018; Lorthongpanich et al., 2012; Morris et al., 2012; Tagawa et al., 2008; Tang et al., 2011; VerMilyea et al., 2011). Mechanical and chemical-mechanical bisection can be performed in various liquid environments, to name but a few: calcium-magnesium-free phosphate-buffered saline (Katayama et al., 2010; Roberts et al., 2011), sodium-chloride supplemented with glucose, pyruvate, lactate and albumin (Casser et al., 2017), Dulbecco 'A' solution with EDTA and albumin (Tarkowski et al., 2001) or M2 medium supplemented with cytochalasin B (Sotomaru et al., 1998). Regarding the biopsy of blastomeres from a cleavage-stage embryo, the ZP is dissolved in one area by a gently controlled flow of Tyrode's solution directed against the ZP; an aspirating pipette is inserted through this opening to remove individual blastomeres (IIImensee et al., 2005; Willadsen, 1979).

The second technique, the bisection of morulae and blastocysts, is performed using a sharp needle or microblade to cut the morula or blastocyst into 2 halves, with the ICM being divided into roughly equal cell numbers. This technique of morula and blastocyst bisection is applied mostly in large mammalian species such as sheep (Gatica et al., 1984; Szell and Hudson, 1991; Willadsen and Godke, 1984), cattle (Ozil et al., 1982; Williams et al., 1984), goat (Tsunoda et al., 1985; Udy, 1987) and pig (Nagashima et al., 1989).

\section{Implementation of monozygotic polyembryony for breed- ing purposes: monozygotic twinning in sheep}

The first attempts to split embryos from farm animals were performed in sheep. In the late 1970s, Willadsen bisected 2-cell stage sheep embryos by removing them individually from the $\mathrm{ZP}$, before injecting single blastomeres into evacuated ZPs and embedding them in cylinders of agar for temporary in vitro culture (Willadsen, 1979). These cylinders were then transferred to the oviduct of ewes and recovered after 3.5-4.5 days to investigate

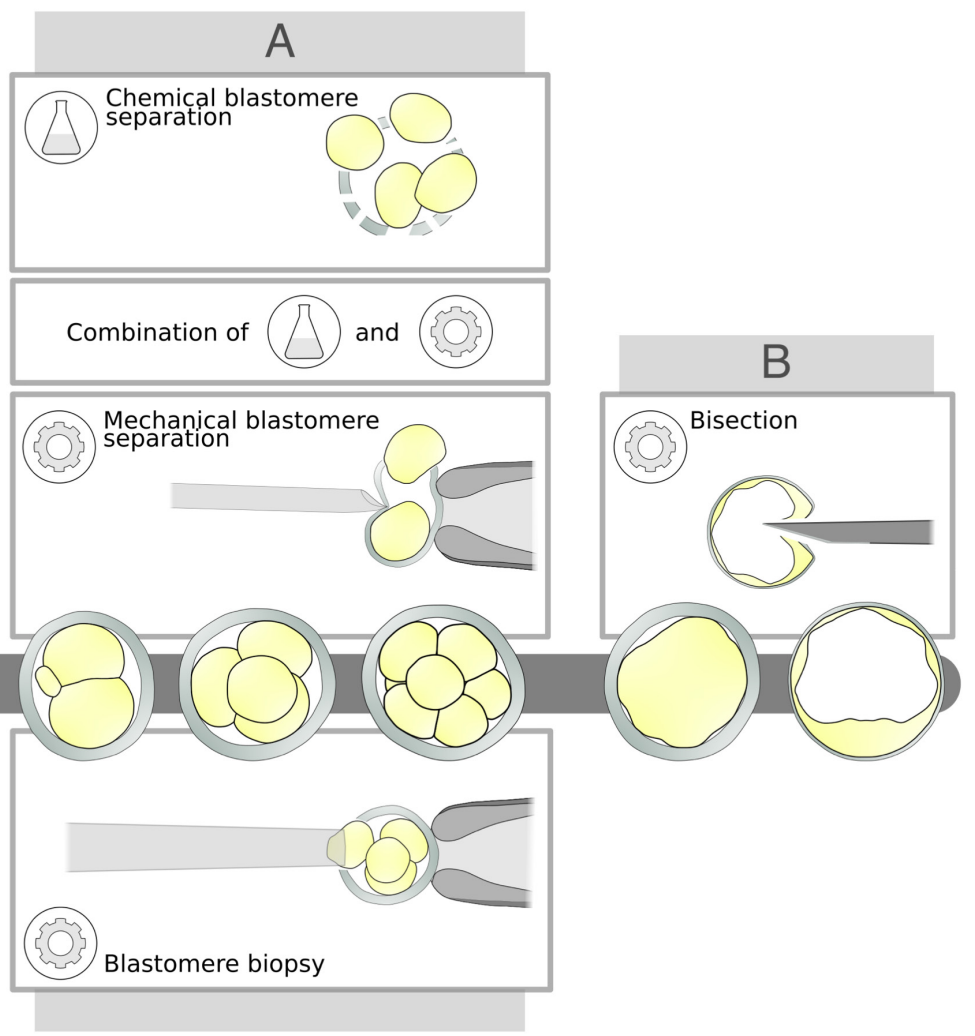

the developmental stage of the twin embryos. Sixteen of $31 \mathrm{MZ}$ twin pairs transferred reached the expected late morula/early blastocyst stage in both partners. These 16 twin pairs were carved out of the agar and transferred back to 16 ewes, resulting in 11 pregnancies of which 10 carried to term with live-born lambs of 5 twin pairs and 5 singles. This was the proof of principle that the artificial production of $\mathrm{MZ}$ twins by 2-cell stage embryo bisection is feasible in sheep. Considering the starting number of 61 bisected 2-cell stage embryos, i.e. 122 potential lambs, the overall outcome (measured in live-born lambs) only comes to $12 \%$, in contrast to the $52-58 \%$ of unmanipulated sheep embryos at that time (Moor and Trounson, 1977; Rowson and Moor, 1966). This comparatively low rate was due to the loss of most of the twin embryos during the bisection and agar-embedding procedure: Only 31 pairs of twins, i.e. 62 embryos, were transferred to ewes, showing that it was not the developmental potential of the manipulated embryos that was prohibitive but the not yet technically mature bisection and in vitro culture technique. If these technical hurdles are left behind and counting starts from the embryo transfer, then 15 lambs correspond to a $47 \%$ birth rate of all blastocysts retransferred $(n=32)$, and 94 $\%$ of the initial number of zygotes $(n=16)$, preluding to the possibility to create more animals than the actual number of zygotes - a possibility crowned in cattle (see next section and Table 1). Thus, it appears that the procedure had to be optimized before it could be used as an effective method to generate embryos of a desired geno- or phenotype reliably, or as a means of reducing experimental animal numbers. In further experiments, Willadsen started to test different preimplantation stages of sheep embryos for the developmental capacity of individualized and paired blastomeres as well as of bisected morulae and blastocysts. He dissociated 4-cell embryos to single blastomeres and 8-cell embryos to single 
TABLE 1

\section{RECAPITULATION OF SELECTED EMBRYO BISECTION STUDIES WITH RESPECT TO EMBRYO MULTIPLICATION AND FULL-TERM DEVELOPMENT}

\begin{tabular}{|c|c|c|c|c|c|c|c|c|c|c|}
\hline \multirow[t]{2}{*}{ Species } & \multirow[t]{2}{*}{ Study } & \multicolumn{5}{|c|}{$\begin{array}{c}\text { Bisection stage } \\
\text { (2-, 4-, 8-cell, morula, } \\
\text { blastocyst) }\end{array}$} & \multirow[t]{2}{*}{$\begin{array}{l}\text { No. of original } \\
\text { embryos }\end{array}$} & \multirow[t]{2}{*}{$\begin{array}{l}\text { No. of transferred } \\
\text { twin embryos }\end{array}$} & \multirow[t]{2}{*}{$\begin{array}{l}\text { Living } \\
\text { offspring }\end{array}$} & \multirow[t]{2}{*}{$\begin{array}{l}\text { Outcome of original } \\
\text { embryo no. [\%] }\end{array}$} \\
\hline & & 2 & 4 & 8 & M & B & & & & \\
\hline \multirow[t]{2}{*}{ rabbit } & Moore et al., 1968 & $\mathrm{x}$ & $\mathrm{x}$ & $\mathrm{x}$ & & & 62 & 214 & 43 & 69,4 \\
\hline & & \multicolumn{5}{|c|}{ control } & \multicolumn{4}{|c|}{ Study does not include transfer of control embryos. } \\
\hline \multirow[t]{4}{*}{ sheep } & Willadsen, 1979 & $\mathrm{x}$ & & & & & 16 & 32 & 15 & 93,8 \\
\hline & Willadsen, 1981 & & $\mathrm{x}$ & $\mathrm{x}$ & & & 14 & 56 & 18 & 128,6 \\
\hline & Willadsen and Godke, 1984 & & & & $\mathrm{x}$ & $\mathrm{x}$ & 18 & 36 & 25 & 138,9 \\
\hline & & \multicolumn{5}{|c|}{ control } & \multicolumn{4}{|c|}{ Studies do not include transfers of control embryos. } \\
\hline \multirow[t]{12}{*}{ cattle } & Willadsen and Polge, 1981 & \multicolumn{5}{|c|}{$\mathrm{x}$} & 7 & 24 & 6 & 85,7 \\
\hline & Ozil et al., 1982 & & & & & $\mathrm{x}$ & 14 & 28 & 15 & 107,1 \\
\hline & Ozil, 1983 & & & & & $x$ & 22 & 33 & 17 & 77,3 \\
\hline & Lambeth et al., 1983 & & & & $\mathrm{x}$ & $x$ & 14 & 24 & 11 & 78,6 \\
\hline & Williams et al., 1984 & & & & $\mathrm{x}$ & $\mathrm{x}$ & 165 & 330 & $157^{*}$ & 95,2 \\
\hline & Williams and Moore, 1988 & & & & & $x$ & 23 & 46 & $14^{\#}$ & 60,9 \\
\hline & Seike et al., 1989 & & & & $\mathrm{x}$ & $x$ & 30 & 59 & 43 & 143,3 \\
\hline & Suzuki et al., 1991 & & & & & $x$ & 115 & 230 & 45 & $39,1^{ \pm}$ \\
\hline & Johnson et al., 1995 & \multicolumn{3}{|c|}{$x$} & & & 2 & 8 & 6 & 300,0 \\
\hline & Tagawa et al., 2008 & $\mathrm{x}$ & & $\mathrm{x}$ & & & 40 & 80 & 25 & 62,5 \\
\hline & Hashiyada et al., 2017 & $x$ & & & & & 28 & 56 & 24 & 85,7 \\
\hline & Seike et al., 1989 & \multicolumn{4}{|c|}{ control } & & 44 & 44 & 26 & 59,1 \\
\hline \multirow[t]{2}{*}{ horse } & Allen and Pashen, 1984 & $\mathrm{x}$ & $\mathrm{x}$ & $\mathrm{x}$ & & & 11 & 20 & $9^{+}$ & 81,8 \\
\hline & & \multicolumn{5}{|c|}{ control } & \multicolumn{4}{|c|}{ Study does not include transfers of control embryos. } \\
\hline \multirow[t]{3}{*}{ mouse } & Tsunoda and McLaren, 1983 & \multirow{2}{*}{\multicolumn{3}{|c|}{$\mathrm{x}$}} & \multirow{2}{*}{\multicolumn{2}{|c|}{$\mathrm{x}$}} & 336 & 672 & 45 & 13,4 \\
\hline & Casser et al., 2017 & & & & & & 118 & 236 & 40 & 33,9 \\
\hline & Tsunoda and McLaren, 1983; Casser et al., 2017 & \multicolumn{5}{|c|}{ control } & 88 & 88 & 37 & 42,0 \\
\hline
\end{tabular}

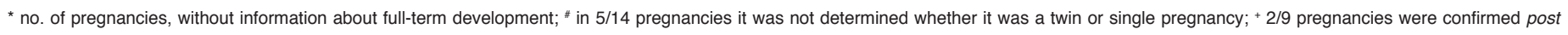
mortem and did not continue to term; lower developmental outcome after freeze/thawing embryo transfer

blastomeres and pairs of blastomeres, respectively, and proceeded as previously described for the 2-cell stage embryos (Willadsen, 1981). After recovery from the temporary recipients with a rate of $86-92 \%$, embryos were examined for their developmental stage: A total of $82 \%$ of the 4 -cell stage blastomeres, $85 \%$ of the single 8 -cell stage blastomeres and $98 \%$ the 8-cell stage blastomere pairs made it to the desired late morula/early blastocyst stage. If all multiplets of one original embryo had developed to late morula/early blastocyst stage and been recovered, they were transferred back to ewes. Transfers to recipients that were observed in a synchronous estrus with the respective donors resulted in birth rates of $38 \%$ out of 8 transferred embryos generated from 2 separated 4-cell stage embryos, and $56 \%$ out of 16 transferred embryos developed from blastomere pairs of 4 quadrisected 8-cell stage embryos. Importantly, one of the original 2 separated 4-cell embryos and 3 of the original 4 quadrisected 8-cell embryos bore MZ multiplets, including a complete set of live-born $\mathrm{MZ}$ quadruplets developed from a quadrisected 8-cell embryo. Furthermore, Willadsen and Godke also obtained embryos in the morula and blastocyst stage from donor ewes, bisected the embryos and transferred the $M Z$ pairs back to the donor (Willadsen and Godke, 1984). These authors remarked that the technique of bisecting an embryo in morula or blastocyst stage is much easier than the isolation of single blastomeres from earlier stages. Their experiments also revealed a higher success rate of embryo transfers and $M Z$ twin lamb generation of embryos bisected in the blastocyst stage: A total of $73 \%$ of transferred twin blastocysts resulted in live-born lambs, $53 \%$ were $\mathrm{MZ}$ twin pairs, while bisection at the morula stage yielded a birth rate of $33 \%$ with no $\mathrm{MZ}$ twins at all. Out of all the experiments performed by Willadsen and colleagues, the highest rate of development to term was achieved when bisecting the latest preimplantation stage, containing more cells, compared to all earlier stages. On a per-embryo basis, the most MZ siblings were obtained when separating an 8-cell stage embryo to 4 blastomere pairs. Clearly, the multiplication rate is higher for 8-cell embryos divided into 4 pairs of blastomeres (4X) compared to 4-cell embryos divided into 2 pairs of blastomeres (2X), and the chance of bearing twins in the former case is higher than in the latter case due to this simple arithmetic reason.

\section{Cattle: a zenith of experimental monozygotic polyembryony in mammals}

After pioneering work in sheep, most attempts to generate $M Z$ multiplets in mammals took place in cattle. The technology of $M Z$ twin generation for breeding purposes was introduced to dairy cattle in the 1980s, with the first registration of MZ calves generated from spilt and transferred embryos by the Holstein Association USA in 1982. This technology was promising to increase the prevalence of offspring with desired genetics and characteristics - in a shorter period of time than normal breeding. There were 2319 twin animals registered at the Holstein Association USA, 1536 females and 783 males, between 1982 and 2002 (Norman et al., 2004). Thousands of artificial twin calves have been born worldwide without any indication of acute abnormalities and, subsequently, the health of these animals remained indistinguishable from that of non-manipulated 
counterparts (Lewis, 1994; Wood and Trounson, 2000). This is in contrast to naturally/spontaneously occurring monochorionic twins, which can occasionally experience health problems (e.g. feto-fetal transfusion syndrome in humans) (Wood and Trounson, 2000).

Among the first researchers who tried to generate $M Z$ multiplets in cattle were Willadsen and Polge (Willadsen and Polge, 1981). Since Willadsen had already proven that it was possible to produce not only twins, but even quadruplets out of a single embryo in sheep, they attempted the same procedure in cattle, separating 8-cell stage embryos into 4 groups of 2 blastomeres each. Since in vitro culture of bovine embryos was not advanced enough at that time, the separated embryos were embedded in agar and then transferred to genital tract of ewes in anestrus. When they reached blastocysts stage, they were recovered, released from agar and transferred to a heifer. This technique resulted in a blastulation rate of $77 \%$ from the preimplantation embryos recovered. After the transfer of 24 quadruplet embryos to 13 foster heifers, 4 pregnancies led to live births of 6 calves (25 $\%$ ): One single calf, a pair of $M Z$ twins and a set of $M Z$ triplets. It is noteworthy that 5 of the 13 pregnancies ended in abortion or the calves died at birth. Although this method enabled the birth of multiple progeny from one embryo, the generation of a complete set of live-born MZ quadruplets was not successful; and the high number of dead fetuses led Willadsen and Polge to question whether these shortcomings were due to the culture conditions and preimplantation development in the oviduct of a different species, or were due to the procedure of blastomere separation and, thus, reduction of embryo cell number per se. Based on the technique developed, described and published by Willadsen and others, Ozil and colleagues went on to improve the procedure. They set out to bisect bovine embryos in the early blastocyst stage recovered from donors at day 6 to 7 after insemination by cutting into 2 halves and replacing each in an emptied ZP (Ozil et al., 1982). These $M Z$ twins were transferred directly pairwise to 14 foster mothers, resulting in 9 pregnancies with 15 fetuses (53.5\%), including 6 pairs of $\mathrm{MZ}$ twins. Compared to the study by Willadsen and Polge mentioned above, this seems to be a much higher developmental rate, but whether all these fetuses would have developed to term and resulted in living offspring remains unknown, since 7 of the 9 pregnant heifers were slaughtered at day 32 or 70 , respectively. Nevertheless, all pregnancies that were allowed to go to term gave rise to 2 pairs of $M Z$ twin calves and, by accruing 15 fetuses out of 14 split embryos (107\%), the original reproductive capacity of the starting embryos was exceeded (Table 1). This increase relative to the whole embryo transfer was also recorded by other research groups. Lambeth and colleagues bisected embryos at day 6.5 to 7 , thus, late morulae to early blastocysts, transferred the twin embryos either as pairs or individually, and obtained 6 pregnancies out of 14 transfers in total, one after transfer of a single embryo, and 5 after transfers of twin embryos (Lambeth et al., 1983). Just as described in the study of Willadsen and Polge (Willadsen and Polge, 1981), Lambeth and colleagues also reported abortions from 2 of the pregnancies ascertained without any clear abnormalities detected in the fetuses. Since this phenomenon had already been reported by other researches (Willadsen and Polge, 1981), Lambeth and colleagues claimed it might be a problem caused by the induction of multiple pregnancies in cattle. Interestingly, most of the pregnancies counted arose from the transfer of twin pairs compared to transfers of singlets, and all recognized pregnancies resulted from bisected morulae and none from bisected blastocysts. A total of 8 pairs of $M Z$ twins and 6 single twin embryos were transferred to 14 recipients, resulting in 11 live-born calves (79\%) (Table 1) including 5 pairs of $\mathrm{MZ}$ twins. Ozil also faced the problem of failed pregnancy from embryos that were split in the blastocyst stage, but managed to overcome it (Ozil, 1983). Changing the way to cut blastocysts at day 8 , from fine glass needles or glass micro-instruments to a custom-designed micro-scalpel on an adjustable support, the cut was cleaner and he generated offspring successfully, including singlets and twins. The reproductive capacity of the starting embryos was also exceeded in this case, with 17 fetuses obtained from the transfer of 11 pairs of $\mathrm{MZ}$ twins and 11 single twin embryos (77\%) (Table 1). The microsurgical blade technique was also adopted by Williams and colleagues, who went further by examining pregnancy rates after microsurgical blade bisection of embryos with different ages (day 5.5 to 7.5) and different developmental stages (early morula to blastocyst) (Williams et al., 1984). Embryos in the early morula, compacted morula, early blastocyst and blastocyst stage were collected between days 5.5 and 7.5 post-estrus from donor cattle, revealing an increase in the pregnancy rate with advanced embryonic age and preimplantation stage. While bisected embryos were retransferred into a surrogate ZP in all the studies mentioned above, later studies tested its necessity and found comparable pregnancy rates after bisecting post-compaction embryos and transferring them without ZP (Warfield et al., 1986; Williams and Moore, 1988). These 2 findings, the increase in pregnancy rates after embryo bisection in more advanced preimplantation stages and the redundancy of surrogate ZPs, were facilitating the whole bisection procedure. Since then, the major requirement for success was a sharp microblade for cutting instead of a professional micromanipulator, an experienced operator and emptied ZPs, providing an easy and efficient method overall to obtain more than $100 \%$ of progeny from the starting number of embryos (Seike et al., 1989; Williams and Moore, 1988). This simplification opened the door for breeding and research advances, and the evolving techniques became more and more optimized. For example, the first freezing and thawing protocols for bovine embryos provided the opportunity to store embryos before or after bisection for analysis at a later time point, or to postpone the embryo transfer to a better time when sufficient recipients would become available (Niemann, 1985; Suzuki et al., 1991). Among other techniques, such as somatic cell nuclear transfer (cloning) and intracytoplasmic sperm injection (ICSI), bisection of embryos is numbered among the few techniques that can improve livestock breeding practices (Ushijima, 2005). Research groups try to improve bisection procedures and culture conditions, as exemplified by the "Well of the Well" (WOW) culture system, in which embryos are cultured individually in conical microwells that have been punched into the bottom of a plastic culture dish and are covered by a microdroplet of medium (Hashiyada et al., 2018; Tagawa et al., 2008; Vajta et al., 2000). Irrespective of technical improvements, previous findings have been confirmed. For example, as researchers succeeded in achieving comparable developmental rates after bisection of earlier (2-cell) and later (8-cell) embryos, the production rate of $\mathrm{MZ}$ twins remained low when embryos were bisected in the earlier 2-cell stage (Tagawa et al., 2008).

Bovine $\mathrm{MZ}$ twins and multiplets are not only of high interest for livestock breeding, but also for basic research. Thus, there are several studies comparing the similarities between $M Z$ twins. By 
way of example, these genetically identical pairs were examined for reproductive parameters, such as semen quality (Braun et al., 1990; Galli et al., 1997; Lessard et al., 2003) or the variation of success of oocyte pick up and in vitro fertilization and preimplantation development (Machado et al., 2006), unveiling less variability between $\mathrm{MZ}$ twins than among non-related donors. Monozygotic twins are also used for comparative studies to investigate the impact of (environmental) factors by measuring changes when one of the twins is subjected to a specific condition while the other one is kept under the original conditions. Using this model, Klein and colleagues explored the molecular dialogue between embryo and mother during pregnancy, revealing transcriptomic changes in the endometrium, ascribed to be induced by the embryo (Klein et al., 2006). The nonpregnant MZ twin of the dam was taken as the genetically identical reference. The third way to make use of $M Z$ twins in basic research is to build on the assumption that identical twins show less variation than non-related individuals and, thus, facilitate the comparability of results within a study. This comes into general use when animals or their physiology are examined, such as the deposition of intramuscular fat (Okumura et al., 2007) or energy balance (Hotovy et al., 1991). A comprehensive analysis of the utility of artificial twinning in basic research is presented later.

\section{Stage of embryo bisection matters: lessons from sheep, cattle and other mammalian species}

The experiments performed in sheep exposed differences in embryo quality and viability depending on the embryonic stage at which bisection had been performed. Tests in bovine, on the contrary, revealed no differences in rates of pregnancies or twins born after transfer of embryos that were separated at the 2-cell stage and of those that were bisected in the morula or blastocyst stage (Tagawa et al., 2008). Thus, the extent to which embryos keep their developmental potential after bisection may be species-specific.

While it has been possible to generate living offspring from separated and cultured single blastomeres from 4- and 8-cell stage embryos in rabbit (Moore et al., 1968), sheep (Willadsen, 1981), cow (Willadsen and Polge, 1981) and horse (Allen and Pashen, 1984), a full outcome for all blastomeres of the same embryo was seldom the case. At the 4-cell stage, only one study generated a full set of 4 live-born $\mathrm{MZ}$ calves by the separation of one 4-cell embryo (Johnson et al., 1995). Furthermore, only one study succeeded in the generation of a complete set of live-born $\mathrm{MZ}$ quadruplets in sheep by the quadrisection of an 8-cell stage embryo (Willadsen, 1981). Full outcome appears to be even more difficult to achieve when it comes to a smaller mammalian species such as mice. Admittedly, 'quarter' mouse embryos are able to form blastocysts, but the ability to implant and form the egg-cylinder stage in vivo is the exception, and the embryos will not develop to term (Rossant, 1976; Tarkowski, 1959b). Isolated single blastomeres of an 8-cell stage mouse embryo do not even form proper blastocysts, at best, they can form blastocyst-like structures which lack an ICM (Rossant, 1976).

The more advanced the developmental stage of the embryo at the time of separation, the smaller the size of the individual cells. Thus, 2 criteria are suggested to play a crucial role for the successful formation of a viable blastocyst after blastomere separation: 1) The number of remaining cells (Willadsen, 1981), and 2) if the blastomeres are singularized, the size of the individual cell
(Tarkowski and Wroblewska, 1967). Blastocyst formation starts at the same time in the bisected embryo as it does in the nonmanipulated, whole embryo, i.e. morphogenesis is supported by fewer cells when it first comes to a differentiation into embryonic and extraembryonic cell lineages. Therefore, the fewer cell(s) of the bisected embryos need to comprise enough material to give rise to all 3 founder cell lineages: The PE and the EPI, which form the ICM, and the extraembryonic cell lineage, the TE (Fig. 1). However, the mouse oocyte is smaller compared to other mammals (Rahman et al., 2008), as well as its blastocyst is at the time of implantation (Eakin and Behringer, 2004). Accordingly, it is assumed that after the bisection of 4- and 8-cell stage mouse embryos, the decreased cell numbers during blastocyst formation are not sufficient to form a proper ICM and, thus, a viable embryo (Rossant, 1976). In line with this assumption, production of viable and fertile offspring of 'quarter' and even 'eighth' mouse embryos was successful, but only if they were supported by tetraploid carrier blastomeres. The latter were increasing the total cell number of the embryos by aggregation, resulting in chimeric blastocysts, capable of full development (Tarkowski et al., 2001,2005; Valer Carstea et al., 2007). Another method to mitigate the cell number deficit is to separate the cells at a later stage and make use of the second technique described above, the cutting of morulae and blastocysts. When mouse embryos were divided into 2 demi-embryos of equal cell numbers at the 8-cell or compacted stages, very low developmental rates were achieved, but some living offspring were obtained, because, although cell numbers were reduced by bisection, they were still sufficient to build a proper embryo in a few cases. Nevertheless, this bisection at the 8-cell stage could not keep up with the developmental rates of embryos separated at the 2-cell stage (Tsunoda and McLaren, 1983). Comparing the survival rates of mouse embryos bisected in morula or blastocyst stages, MZ twins derived from blastocyst stage embryos showed the highest developmental rates in vitro. Interestingly, they also implanted with rates comparable to those of non-bisected control embryos, but their potential for postimplantation development was significantly decreased. This was ascribed to the diminution of cell numbers in the ICM due to the bisection procedure. Consequently, the embryos failed in the egg-cylinder formation (Wang et al., 1990).

\section{Challenges pending and requirements of experimental monozygotic polyembryony}

The generation of $\mathrm{MZ}$ twins or multiplets for breeding or research purposes is an artificial process for which the embryos are removed from the donor, bisected, eventually cultured in vitro and then transferred to the recipient, a foster mother. On the one hand, each of these steps needs to be adjusted to mimic the natural conditions as much as they can be to preserve embryo quality. On the other hand, interventions also need to provide the possibility for manipulation and storage and the flexibility for multiple applications. Since proper formation of preimplantation structures in bisected embryos is less supported by their reduced cell number, these halved embryos also represent an appropriate model to investigate the right techniques to culture and handle invasively manipulated embryos. If these 'halved' embryos make it through implantation and gastrulation, their health status after birth is considered to be indistinguishable from that of intact embryos. There may be hints of lighter body weight in twins, but the limited 
number of cases reported precludes firm conclusions (Allen and Pashen, 1984; Casser et al., 2017; Gärtner and Baunack, 1981; Papaioannou et al., 1989).

Since the embryos must be removed from a donor to be bisected, each resulting embryo has, in most cases, 2 mothers: An oocyte or embryo donor and a recipient, posing additional requirements for the successful gestation. The synchrony between the estrus of the donor and the estrus of the recipient, for example, is an important factor for the success of transferred bisected embryos. If donor and recipient estruses are synchronized, the viability of less advanced embryos such as quadrisected embryos is enhanced (Willadsen, 1981). A +/- 24 hour difference of the onset of estrus is tolerable with negligible differences in birth rates in sheep (Szell and Hudson, 1991), but any larger asynchrony results in fewer or even no offspring. Generally, the more advanced the developmental stage of the embryo, the better its viability despite the asynchrony of estruses (Rowson and Moor, 1966). In sheep, it was also shown to be beneficial to twin embryo development if the embryos were transferred to recipients that had more than one ovulation during the estrus of transfer (Szell and Hudson, 1991). Monozygotic twin blastocysts generated by bisection of mouse embryos in the blastocyst stage revealed that it is not only important to have synchrony in estruses, but also to provide extra time for the embryo to propagate its cells in an in vivo environment before implanting to the uterus (Wang et al., 1990).

Another important issue of multiplet embryo handling is their storage. Monozygotic multiplets of an embryo, for instance, may be stored for use at a subsequent time, while one is transferred to a foster mother and carried to full term to be examined for specific characteristics, or to investigate and compare development, developmental potential or the impact of manipulations or environment on the multiplets. Thus, the possibility of obtaining $\mathrm{MZ}$ twins at different time points by freezing and thawing is a useful tool, especially for breeding purposes (Seike et al., 1991). When bisected ZP-free goat twin embryos were transferred to foster mothers after a cycle of freezing and thawing, they showed a diminished viability in comparison to twin embryos that were transferred directly after blastocyst bisection (Nowshari and Holtz, 1993). The same was found in mice: Potential for preimplantation development of bisected embryos that underwent a cycle of freezing and thawing was lower than the potential of freshly bisected embryos, whereby earlier bisected and frozen stages (4- to 8-cell) appear to be more robust during this procedure than later stages (late morula to early blastocyst) (Sotomaru et al., 1998). Regarding frozen and thawed demi-embryos, the natural shelter of the single embryo, the ZP, also plays an important role. Seike and colleagues examined the importance of such a shelter in the form of the ZP or an embedding in agar and found no differences in terms of developmental rates, either pre- or postimplantationally, for whole, non-separated bovine embryos (Seike et al., 1991). Regarding bisected embryos, pregnancy rates were significantly decreased for embryos that were frozen and thawed without a ZP. During the bisection procedure, the ZP is necessarily damaged or even removed from the embryos: The ZP is either cut or chemically dissolved by pronase or acidified Tyrode's solution or the blastomeres are mechanically extracted out of a slit made in the ZP. Thus, from the time of bisection, the embryos are in direct contact with the surrounding media and are directly exposed to the change of state from liquid to solid. Thus, although in vitro culture with or without ZP does not have any significant effect on postimplantation rates, cycles of freezing and thawing on embryos without ZP diminish the subsequent embryos' quality and viability (Sotomaru et al., 1998). An exemplary solution to this problem is the usage of agarose capsules, which were first tested in mouse, but which are also suggested as a suitable protection for livestock and human embryos (Nagatomo et al., 2017).

\section{More than just breeding livestock: utility of artificial twinning in basic research}

The artificial generation of $\mathrm{MZ}$ twins has been highly conducive to improve breeding by providing the opportunity to obtain more progeny of a desired geno- and phenotype. It also offers the possibility of selectively propagating a desired characteristic by analyzing the one $\mathrm{MZ}$ twin and breeding the other. Monozygotic twins, for instance, have been very useful while searching for aesthetics, such as a high degree of marbling in cattle (Hashiyada, 2017). In addition to these uses, $\mathrm{MZ}$ twins are also a highly valuable tool in basic research. High numbers of experimental individuals are essential in some settings to statistically confirm findings from basic research. In the case of embryo production, $\mathrm{MZ}$ twins provide an opportunity to reduce experimental animal numbers, because 1) a single zygote is giving rise to more than just one embryo or individual (Table 1), and 2) the same genetic origin affords reduction of variation in test groups. Accordingly, whether the use of $\mathrm{MZ}$ sheep twins - which are assumed to be clones of one another - enables enhanced statistical reliability and, thus, reduction of animal numbers was examined. As anticipated, for characteristics that are more affected by genetics than by environmental factors, such as adult weight and circumference of testicles, researchers found less variation within pairs of $\mathrm{MZ}$ twins than between them, a clear example of a reduction of animal numbers. Interestingly, this does not apply to physiological processes such as those of the endocrine system and processes relying on it (Celi et al., 2007). Consequently, the use of $\mathrm{MZ}$ twins is not always appropriate if the aspect of interest is influenced by several variables and needs to be considered on a case by case basis.

If variation in test groups is still high despite the use of genetically identical twins, then experimental animal numbers must be kept high to afford sufficient statistical power. Reaching these numbers may prove harder for the larger mammalian species of livestock than for small laboratory species. The model of identical twins, for instance, is more cost-effective to perform in mice, since reproduction time is substantially shorter, mice are easier to handle, less demanding and expensive to breed, and can be housed at a comparatively higher density. Another advantage of using mice to artificially generate $\mathrm{MZ}$ twins to produce a highly homogenous test cohort are the mouse strains for laboratory usage already well-established, i.e. mouse strains that already feature quite an identical genetic background. This is beneficial, since it is claimed to be important that $\mathrm{MZ}$ twins should originate from a homogenous population to keep the numbers of animals required down (Biggers, 1986). Additionally, mice, a litter-bearing, polytocous species, afford the opportunity to transfer both $\mathrm{MZ}$ twins or even more multiplets to a single foster mother without involving the danger of severe complications due to a multiple pregnancy, as can be the case in cattle and horse (Giles et al., 1993; Lopez-Gatius et al., 2004). By using the same foster mother, $\mathrm{MZ}$ twins are developing in the 


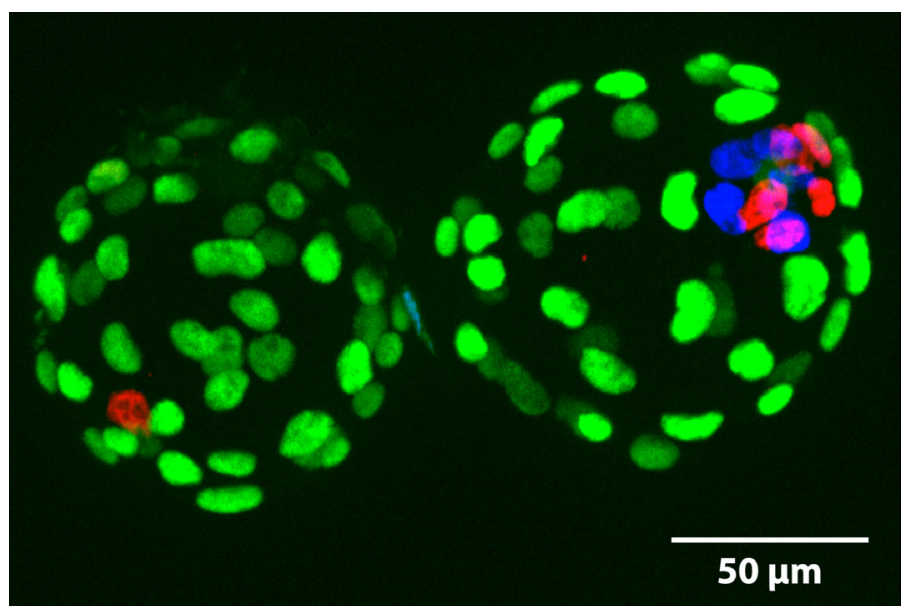

Fig. 3. Discordant MZ mouse twin embryos. Immunoconfocal fluorescence image of discordant $M Z$ twin blastocysts (E4.5), co-stained for cell lineage-specific markers: CDX2 for TE (green), SOX17 and NANOG for the ICM lineages of PE (blue) and EPI (red), respectively. While both twins developed a sufficient number of TE cells to implant in a uterus, the ICM of the left twin exhibits no PE and only one single cell in its EPI, suggesting its non-viability (Morris et al., 2012). Microscope objective 20X, 0.75 N.A.

same environment and experiencing the same conditions, which enhance the similarities and, thus, the comparability of twin pairs, since the interference of different treatments can be excluded or at least minimized (Biggers, 1986).

Mullen and colleagues (1970) and Moustafa and Hahn (1978) were the first to derive MZ twin embryos in mice. These embryos find use predominantly in basic research, for example, to investigate regulatory processes in development. When embryo bisection was performed at the 8-cell stage, the resultant $M Z$ twins had a greater degree of reciprocal similarity than DZ twins - even though both classes of twins stemmed from an inbred strain and, therefore, the 2 groups were expected to have same genotypic variance (Gärtner and Baunack, 1981). This unexpected result was ascribed to non-genetic influences on the zygote as far as the third cleavage stage, whereby different zygotes (DZ twins) experience these influences to different extents, whereas if a zygote is bisected after the third cell division, the modification is decisive for both $M Z$ partners in the same way. Notably, the MZ twins produced by bisection at the 8-cell stage were also less variable in behavioral terms (Baunack et al., 1984; Freund et al., 2013). This effect was named "intangible variance" and was considered to be an accident of development, whereas, in fact, it was a demonstration of epigenetics long before epigenetics had been described in molecular terms. A further example of how $\mathrm{MZ}$ twin mice make a useful animal model for examining regulatory processes in development is the case of the effect of genes-environment interaction on either the prenatal dentocraniofacial morphogenesis or the postnatal craniofacial growth (Watanabe et al., 1998).

Another interesting aspect of research are the developmental capacities and properties of these artificially generated identical twins and their precursor blastomeres. It was found that twin embryos that were bisected at the earliest possible time point, the 2-cell stage, exhibited unequal ICM sizes in spite of synchrony in cleavage timing (Fig. 3). In many cases, they had compara- tively small ICMs in either one or even both twins, explaining the difficulty of producing MZ offspring (Katayama et al., 2010). Furthermore, the technique of MZ multiplet production via blastomere biopsy has been used to investigate the determination of cell fate decisions. Cells in 16- and 32-cell stage embryos have undergone their first cell fate decision to become part of the embryonic or extraembryonic tissue. Nevertheless, these cells can still contribute - through their progeny - to multiple lineages within the embryonic tissue, exemplifying their pluripotentiality. It is striking that although the single blastomeres of 16- and 32-cell stage embryos have lost their totipotency, defined as the ability of a single cell to form a complete and fertile organism if hosted in an appropriate environment, these cells are still able to modify the cell fate of their progeny (Tarkowski et al., 2010). The founder cell lineage that gives rise to the embryo proper is the EPI. It became apparent by analyzing the viability of bisected mouse embryos that only those that formed an EPI consisting of at least 4 cells were able to continue developing (Morris et al., 2012). Thus, the use of $M Z$ mouse embryos allowed the establishment of a concept of paramount importance for the understanding of developmental totipotency, namely: Totipotency is not a black and white concept but features the blastomere's ability to accumulate sufficient numbers of progeny cells in a given lineage, in this case the EPI. Not even the 2 blastomeres of the 2-cell stage mouse embryo, which are considered to be totipotent, are both necessarily viable; they can differ in their developmental potential to form a complete organism on their own even in this early stage (Casser et al., 2017) (Fig. 3).

Bisection of 2-cell stage mouse embryos offers the unique possibility of obtaining 2 single cells that originate from one cell. These are analyzed for transcript profiles in order to understand when sibling blastomeres start to diverge from each other (differentiation) (Roberts et al., 2011; VerMilyea et al., 2011), allelespecific gene expression (Deng et al., 2014; Tang et al., 2011), to study cell fate decisions in early preimplantation development (Biase et al., 2014; Goolam et al., 2016), or totipotency, as was just discussed (Casser et al., 2017). Similarly designed studies have also been conducted in bovine (Held et al., 2012) and sheep (Hosseini et al., 2016), but infrequently, probably due to the more complex logistic aspects of in vitro embryo production in large animals.

\section{Opportunities for experimental polyembryony in biomedical research and in humans}

While artificially generated $\mathrm{MZ}$ twins and multiplets offer great opportunities in the fields of directed breeding and basic research, natural human $M Z$ twins are to be looked at from a different perspective. Natural MZ twins in human are rare but not impossible, and less of a risk factor during pregnancy due to modern medical care. To the best of our knowledge, the intentional generation of human $\mathrm{MZ}$ twins is restricted by law. Thus, research on MZ twins is constrained and usually only based on case studies performed on natural $\mathrm{MZ}$ twins, relevant for biomedical research and directly on the patient - and its discordant MZ twin.

Although arising from one zygote and comprising the same genomic information, MZ twins are often discordant in the development and manifestation of (congenital) diseases, such as heart (AIRais et al., 2011; Lyu et al., 2018; Vinograd et al., 2013), 
autoimmune (Kakoulidou et al., 2004; Mustafa et al., 2017) and prion diseases (Hamasaki et al., 1998). Even the severity of the same genomic defect or the onset of a disease which is already inherent can differ between MZ twins (Li et al., 2017; Vencovsky et al., 1995). Thus, genetic comparison of $\mathrm{MZ}$ twins discordant for a disorder can corroborate or confute the association of the disorder itself with a genetic trait (Jerome et al., 2011) and the healthy twin serves as the best control for the discordant affected twin, since their otherwise identical genetic background abolishes variability (Hibaoui et al., 2014). It is noteworthy that initially concordant twins sometimes become discordant owing to epigenetic differences that arise during their lifetime. The genomic distribution and prevalence of 5-methylcytosine DNA and histone acetylation, for example, can diverge between twins, causing changes of gene expression (Fraga et al., 2005). Differences arising between $\mathrm{MZ}$ twins are not necessarily intrinsic to the twins but may also concern, for instance, symbiontic pairs. Research on $\mathrm{MZ}$ twins with discordant caries incidence, for example, revealed the different compositions of the twins' oral microbiota (Wu et al., 2018). In a distinct but related study, MZ twins allowed measurements of how a change in the diet composition results in significant changes in expression of microbiome-encoded enzymes (McNulty et al., 2011).

On the assumption that any differences between MZ twins are due primarily to their environments, the insight we gain from studying twins may help us to understand medical conditions better. These can range from health conditions directly affecting the well-being of patients (diabetes, autism, bipolar disorder, allergies, Alzheimer's disease, some cancers), to those affecting reproduction, where the patient is not necessarily affected, but the next generation is. An exemplary but special case of discordance is that of twins discordant for premature ovarian failure. In this case, ovarian transplantation from the unaffected to the affected twin could be of therapeutic value (Silber et al., 2005). In reproductive medicine, the artificial production of $\mathrm{MZ}$ twins can also help as an alternative to the repetition of ovarian stimulation cycles. The lower the number of successfully generated embryos by in vitro fertilization or ICSI, the lower the chance for a pregnancy and the higher the likelihood of another hormonal treatment cycle of a woman. Such a low number of embryos can be caused by a low number of oocytes obtained after hormonal treatment, by the poor quality of sperm or oocytes due to diseases or due to a cycle of freezing and thawing for storage purposes, or by chromosomal aberrations in the embryo resulting in malformation or death of the embryo. In such a limiting situation, the possibility of embryo multiplication by separating the few available embryos is appealing. In principle, the expansion of embryo numbers might be taken even further via serial splitting and has been performed by Illmensee and colleagues on mouse embryos (IIImensee et al., 2006). Actively induced embryo multiplication is not a common and generally legal practice in human, and the success of bisection procedures tested on nonhuman primate models was shown to be limited. Taken together, concerns have been raised that while the number of embryos can be increased by artificial twinning, their quality lags behind (Chan et al., 2000; Mitalipov et al., 2002; Schramm and Paprocki, 2004; Tang et al., 2012). Nonetheless, embryo splitting has also been tested in human (IIImensee et al., 2011; Illmensee et al., 2010; Noli et al., 2015; Van de Velde et al., 2008). Along these lines, a twin-based method has also been proposed to lower the incidence of hereditary disorders and virtually eradicate simple Mendelian disorders in a human population. Briefly, one of the 2 twin embryos generated in vitro would be transferred to the uterus to establish a pregnancy only if the other twin has already proven to be in good health (Churbanov and Abrahamyan, 2018). The ethical implications of this procedure (eugenics), while clear, are beyond the scope of this review. Since splitting human embryos by blastomere biopsy or separation was reported to not preserve embryo quality and, therefore, to be unsuitable for research or clinical uses (Noli et al., 2017), it seems that the usefulness of human $M Z$ twins in biomedical research may be limited to natural twins, for example to investigate genetic associations (Olivieri et al., 2014).
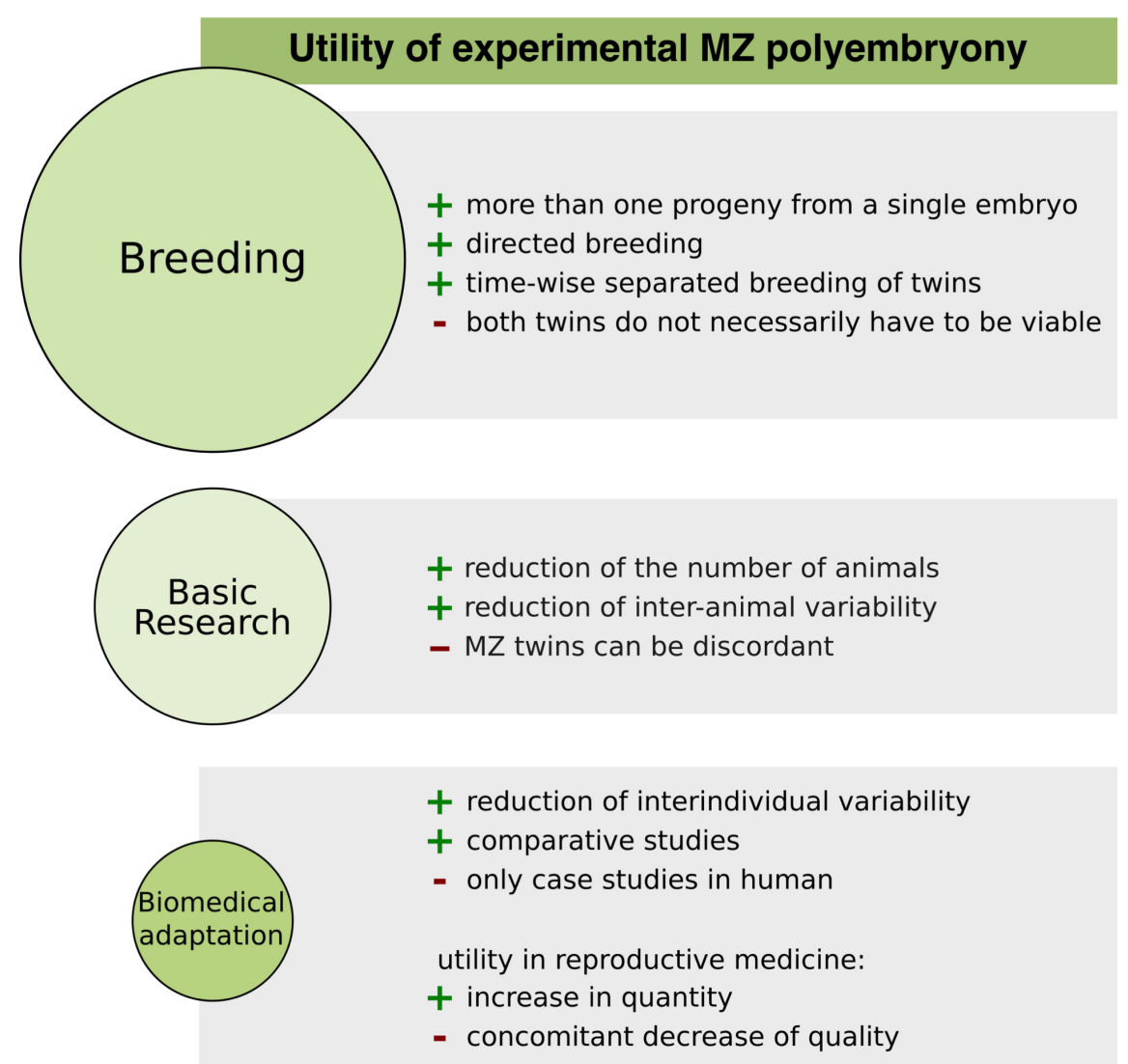

Fig. 4. Fields of application of experimental monozygotic (MZ) polyembryony. All 3 fields of application - animal breeding, basic research, and biomedical adaptation - reveal the advantages and disadvantages of using artificially generated or - in human - natural $M Z$ twins and multiplets. The field of livestock breeding and maintenance profits most from artificial MZ twinning. 


\section{Concluding remarks}

The original motivation for experimental polyembryony - efficiently generating more offspring out of the same zygote - was put to the test in various fields. This review provides an overview of the developments, improvements, challenges, applications and utilities of the artificial generation of $\mathrm{MZ}$ twins and multiplets, whereby 3 fields of application have emerged: animal breeding, basic research, and biomedical adaptation in humans (Fig. 4). Embryo splitting can be advantageous to create additional copies of elite animals or to perform time-wise separated breeding of genotypically identical animals. Even though the 'embryo multiplication rate' can exceed 2, the fetal quality of the blastocysts drops, i.e. MZ polyembryony does not necessarily benefit sexual reproduction efficiency (multiplying the number of offspring per fertilized oocyte) except in cattle (Table 1). Indeed, cattle breeding is the area that benefits most from the usage of $\mathrm{MZ}$ multiplets, followed by sheep. In basic research, the usage of $M Z$ multiplets allows to reduce the number of embryo donors and to enhance the consistency of e.g. molecular or pharmacological assays in animal experiments, since the interindividual variability within tests groups is lower owing to the identical genetic background. However, concordance of $M Z$ twins is not necessarily a given (Fig. 3). Still, the reduced incidence of confounding factors is an advantage which biomedical study designs can also benefit from. In addition, natural human $\mathrm{MZ}$ twin pairs offer the opportunity to perform comparative studies in which one twin serves as the control for the co-twin's specific phenotype, although these comparisons can often only be handled as case studies. A biomedical area that was thought to benefit from the multiplication of embryos is assisted human reproduction, given the limited numbers of gametes due to the impact of infertility. Unfortunately, thus far, it has been shown that splitting human embryos only decreases the quality of the embryos, so this is, up to now, an unsustainable field of application. In conclusion, it appears that mammalian zygotes have the regulative capacity to be polyembryonic, but this is not obligate and its return of investment in breeding, basic research and biomedical application needs to be verified on a case-by-case basis.

\section{Acknowledgments}

We are grateful to Caroline Merino León and Caitlin M. MacCarthy for critical reading and valuable suggestions, and to Philip Saunders for proofreading. This work did not receive specific funding, however, E.C. and M.B. were supported by a grant of the Deutsche Forschungsgemeinschaft (DFG BO 2540-4-3) during the preparation of this work.

\section{References}

ALLEN, W.R. and PASHEN, R.L. (1984). Production of monozygotic (identical) horse twins by embryo micromanipulation. $J$ Reprod Fertil 71: 607-613.

ALRAIS, F., FELDSTEIN, V.A., SRIVASTAVA, D., GOSNELL, K. and MOON-GRADY, A.J. (2011). Monochorionic twins discordant for congenital heart disease: a referral center's experience and possible pathophysiologic mechanisms. Prenat Diagn 31: 978-984.

ASSHETON, R. (1898). An account of a blastodermic vesicle of the sheep of the seventh day, with twin germinal areas. J Anat Physiol 32: 362-372.362.

ASTON, K.I., PETERSON, C.M. and CARRELL, D.T. (2008). Monozygotic twinning associated with assisted reproductive technologies: a review. Reproduction 136: 377-386.

BAUNACK, E., FALK, U. and GÄRTNER, K. (1984). Monozygotic vs. dizygotic twin behavior in artificial mouse twins. Genetics 106: 463-477.
BIASE, F.H., CAO, X. and ZHONG, S. (2014). Cell fate inclination within 2-cell and 4-cell mouse embryos revealed by single-cell RNA sequencing. Genome Res 24: 1787-1796.

BIGGERS, J.D. (1986). The potential use of artificially produced monozygotic twins for comparative experiments. Theriogenol. 26: 1-25.

BJERRE, D., THORUP, F., JORGENSEN, C.B., VEJLSTED, M. and FREDHOLM, M. (2009). A study of the occurrence of monochorionic and monozygotic twinning in the pig. Anim Genet 40: 53-56.

BLICKSTEIN, I., JONES, C. and KEITH, L.G. (2003). Zygotic-splitting rates after single-embryo transfers in in vitro fertilization. N Engl J Med 348: 2366-2367.

BOMSEL-HELMREICH, O. and PAPIERNIK-BERKHAUER, E. (1976). Delayed ovulation and monozygotic twinning. Acta Genet Med Gemellol (Roma) 25: 73-76.

BRAUN, J., SCHAMS, D. and BREM, G. (1990). [The reproductive function in experimentally-produced monozygotic twin bulls]. Berl Munch Tierarztl Wochenschr 103: 213-217.

BRISON, D.R., STURMEY, R.G. and LEESE, H.J. (2014). Metabolic heterogeneity during preimplantation development: the missing link? Human Reprod. Update 20: $632-640$.

CASSER, E., ISRAEL, S., WITTEN, A., SCHULTE, K., SCHLATT, S., NORDHOFF, V. and BOIANI, M. (2017). Totipotency segregates between the sister blastomeres of two-cell stage mouse embryos. Sci Rep 7: 8299.

CELI, P., WALKDEN-BROWN, S.W., BLACHE, D., SZELL, A.Z., WILKINSON, H.M. and MARTIN, G.B. (2007). Twin efficiency for reproductive variables in monozygotic twin sheep. Theriogenol. 68: 663-672.

CHAN, A.W., DOMINKO, T., LUETJENS, C.M., NEUBER, E., MARTINOVICH, C., HEWITSON, L., SIMERLY, C.R. and SCHATTEN, G.P. (2000). Clonal propagation of primate offspring by embryo splitting. Science 287: 317-319.

CHURBANOV, A. and ABRAHAMYAN, L. (2018). Preventing common hereditary disorders through time-separated twinning. Bionanosci. 8: 344-366.

DAY, E., KEARNS, P.K., TAYLOR, C.J. and BRADLEY, J.A. (2014). Transplantation between monozygotic twins: how identical are they? Transplantation 98: 485-489.

DEL RIO, N.S., KIRKPATRICK, B.W. and FRICKE, P.M. (2006). Observed frequency of monozygotic twinning in Holstein dairy cattle. Theriogenol. 66: 1292-1299.

DENG, Q., RAMSKOLD, D., REINIUS, B. and SANDBERG, R. (2014). Single-cell RNA-seq reveals dynamic, random monoallelic gene expression in mammalian cells. Science 343: 193-196.

EAKIN, G.S. and BEHRINGER, R.R. (2004). Diversity of germ layer and axis formation among mammals. Sem. Cell Dev. Biol. 15: 619-629.

ELY, J.J., FRELS, W.I., HOWELL, S., IZARD, M.K., KEELING, M.E. and LEE, D.R. (2006). Twinning and heteropaternity in chimpanzees (Pan troglodytes). Am J Phys Anthropol 130: 96-102.

FRAGA, M.F., BALLESTAR, E., PAZ, M.F., ROPERO, S., SETIEN, F., BALLESTAR, M.L., HEINE-SUNER, D., CIGUDOSA, J.C., URIOSTE, M., BENITEZ, J. et al., (2005). Epigenetic differences arise during the lifetime of monozygotic twins. Proc Natl Acad Sci USA 102: 10604-10609.

FREUND, J., BRANDMAIER, A.M., LEWEJOHANN, L., KIRSTE, I., KRITZLER, M., KRUGER, A., SACHSER, N., LINDENBERGER, U. and KEMPERMANN, G. (2013) Emergence of individuality in genetically identical mice. Science 340: 756-759.

GALLI, A., BORNAGHI, V., PREVITALI, C., BALDUZZI, D. and MORETTI, M. (1997). Andrological study of two young identical twin bulls. Andrologia 29: 115-116.

GÄRTNER, K. and BAUNACK, E. (1981). Is the similarity of monozygotic twins due to genetic factors alone? Nature 292: 646.

GATICA, R., BOLAND, M.P., CROSBY, T.F. and GORDON, I. (1984). Micromanipulation of sheep morulae to produce monozygotic twins. Theriogenology 21: 555-560.

GILES, R.C., DONAHUE, J.M., HONG, C.B., TUTTLE, P.A., PETRITES-MURPHY, M.B., POONACHA, K.B., ROBERTS, A.W., TRAMONTIN, R.R., SMITH, B. and SWERCZEK, T.W. (1993). Causes of abortion, stillbirth, and perinatal death in horses: 3,527 cases (1986-1991). J Am Vet Med Assoc 203: 1170-1175.

GOOLAM, M., SCIALDONE, A., GRAHAM, S.J.L., MACAULAY, I.C., JEDRUSIK, A., HUPALOWSKA, A., VOET, T., MARIONI, J.C. and ZERNICKA-GOETZ, M. (2016). Heterogeneity in Oct4 and Sox2 targets biases cell fate in 4-cell mouse embryos. Cell 165: 61-74.

GOVAERE, J., HOOGEWIJS, M., DE SCHAUWER, C., VAN ZEVEREN, A., SMITS, K., CORNILLIE, P. and DE KRUIF, A. (2009). An abortion of monozygotic twins in a warmblood mare. Reprod Domest Anim 44: 852-854. 
HALL, J.G. (2003). Twinning. Lancet 362: 735-743.

HAMASAKI, S., SHIRABE, S., TSUDA, R., YOSHIMURA, T., NAKAMURA, T. and EGUCHI, K. (1998). Discordant Gerstmann-Straussler-Scheinker disease in monozygotic twins. Lancet 352: 1358-1359.

HASHIYADA, Y. (2017). The contribution of efficient production of monozygotic twins to beef cattle breeding. J Reprod Dev 63: 527-538.

HASHIYADA, Y., AIKAWA, Y., MATSUDA, H., YAMANOUCHI, T., GOTO, Y., OHTAKE, M., SUGIMURA, S. and IMAI, K. (2018). 77 Monozygotic twin calves production by blastomere separation technique with commercial Well-of-the-Well culture dish. Reprod Fertil Dev 30: 177-177.

HELD, E., SALILEW-WONDIM, D., LINKE, M., ZECHNER, U., RINGS, F., TESFAYE, D., SCHELLANDER, K. and HOELKER, M. (2012). Transcriptome fingerprint of bovine 2-cell stage blastomeres is directly correlated with the individual developmental competence of the corresponding sister blastomere. Biol Reprod 87: 154.

HIBAOUI, Y., GRAD, I., LETOURNEAU, A., SAILANI, M.R., DAHOUN, S., SANTONI, F.A., GIMELLI, S., GUIPPONI, M., PELTE, M.F., BENA, F. et al., (2014). Modelling and rescuing neurodevelopmental defect of Down syndrome using induced pluripotent stem cells from monozygotic twins discordant for trisomy 21. EMBO Mol Med 6: 259-277.

HOSSEINI, S.-M., MOULAVI, F., TANHAIE-VASH, N., ASGARI, V., GHANAEI, H.-R., ABEDI-DORCHE, M., JAFARZADEH, N., GOURABI, H., SHAHVERDI, A.-H., DIZAJ, A.V. et al., (2016). The principal forces of oocyte polarity are evolutionary conserved but may not affect the contribution of the first two blastomeres to the blastocyst development in mammals. Plos One 11: e0148382.

HOTOVY, S.K., JOHNSON, K.A., JOHNSON, D.E., CARSTENS, G.E., BOURDON, R.M. and SEIDEL, G.E., JR. (1991). Variation among twin beef cattle in maintenance energy requirements. J Anim Sci 69: 940-946.

ILLMENSEE, K., KASKAR, K. and ZAVOS, P.M. (2005). Efficient blastomere biopsy for mouse embryo splitting for future applications in human assisted reproduction. Reprod Biomed Online 11: 716-725.

ILLMENSEE, K., KASKAR, K. and ZAVOS, P.M. (2006). In vitro blastocyst development from serially split mouse embryos and future implications for human assisted reproductive technologies. Fertil Steril 86: 1112-1120.

ILLMENSEE, K., LEVANDUSKI, M., KONIALIS, C., PANGALOS, C., VITHOULKAS, A. and GOUDAS, V.T. (2011). Human embryo twinning with proof of monozygocity. Middle East Fertil Soc J 16: 215-219.

ILLMENSEE, K., LEVANDUSKI, M., VIDALI, A., HUSAMI, N. and GOUDAS, V.T. (2010). Human embryo twinning with applications in reproductive medicine. Fertil Steril 93: 423-427.

JEROME, K.R., DIEM, K., HUANG, M.L., SELKE, S., COREY, L. and BUCHWALD, D. (2011). Xenotropic murine leukemia virus-related virus in monozygotic twins discordant for chronic fatigue syndrome. Diagn Microbiol Infect Dis 71: 66-71.

JOHNSON, W.H., LOSKUTOFF, N.M., PLANTE, Y. and BETTERIDGE, K.J. (1995). Production of four identical calves by the separation of blastomeres from an in vitro derived four-cell embryo. Vet Rec 137: 15-16.

JOONE, C.J., DE CRAMER, K. and NOTHLING, J.O. (2016). The first case of genetically confirmed monozygotic twinning in the dog. Reprod Domest Anim 51: 835-839.

KAKOULIDOU, M., AHLBERG, R., YI, Q., GISCOMBE, R., PIRSKANEN, R. and LEFVERT, A.K. (2004). The autoimmune T and B cell repertoires in monozygotic twins discordant for myasthenia gravis. J Neuroimmunol 148: 183-191.

KATAYAMA, M., ELLERSIECK, M.R. and ROBERTS, R.M. (2010). Development of monozygotic twin mouse embryos from the time of blastomere separation at the two-cell stage to blastocyst. Biol Reprod 82: 1237-1247.

KIMURA, S. (1957). The twinning in southern fin whales. Sci. Rep. Whales Res. Inst. 103-125.

KLEIN, C., BAUERSACHS, S., ULBRICH, S.E., EINSPANIER, R., MEYER, H.H., SCHMIDT, S.E., REICHENBACH, H.D., VERMEHREN, M., SINOWATZ, F., BLUM, H. et al., (2006). Monozygotic twin model reveals novel embryo-induced transcriptome changes of bovine endometrium in the preattachment period. Biol Reprod 74: 253-264.

KRAAY, G.J., MENARD, D.P. and BEDOYA, M. (1983). Monozygous cattle twins as a result of transfer of a single embryo. Can Vet $J$ 24: 281-283.

KYONO, K. (2013). The precise timing of embryo splitting for monozygotic dichorionic diamniotic twins: when does embryo splitting for monozygotic dichorionic diamniotic twins occur? Evidence for splitting at the morula/blastocyst stage from studies of in vitro fertilization. Twin Res. Hum. Genet. 16: 827-832.
LAMBETH, V.A., LOONEY, C.R., VOELKEL, S.A., JACKSON, D.A., HILL, K.G. and GODKE, R.A. (1983). Microsurgery on bovine embryos at the morula stage to produce monozygotic twin calves. Theriogenology 20: 85-95.

LESSARD, C., MASSEAU, I., BILODEAU, J.F., KROETSCH, T., TWAGIRAMUNGU, H., BAILEY, J.L., LECLERC, P. and SULLIVAN, R. (2003). Semen characteristics of genetically identical quadruplet bulls. Theriogenology 59: 1865-1877.

LEWIS, I. (1994). Splitting cattle embryos commercially: the effects of sucrose, embryo stage and the duration between embryo recovery and bisection. Theriogenology 41: 237.

LI, L., HUANG, L., LIN, S., LUO, Y. and FANG, Q. (2017). Discordant phenotypes in monozygotic twins with 16 p11.2 microdeletions including the SH2B1 gene. Am J Med Genet A 173: 2284-2288.

LOPEZ-GATIUS, F., SANTOLARIA, P., YANIZ, J.L., GARBAYO, J.M. and HUNTER, R.H. (2004). Timing of early foetal loss for single and twin pregnancies in dairy cattle. Reprod Domest Anim 39: 429-433.

LORTHONGPANICH, C., DORIS, T.P., LIMVIPHUVADH, V., KNOWLES, B.B. and SOLTER, D. (2012). Developmental fate and lineage commitment of singled mouse blastomeres. Development 139: 3722-3731.

LOUGHRY, W.J., PROD, XF, HL, P.A., MCDONOUGH, C.M. and AVISE, J.C. (1998) Polyembryony in armadillos: an unusual feature of the female nine-banded armadillo's reproductive tract may explain why her litters consist of four genetically identical offspring. Am Sci 86: 274-279.

LYU, G., ZHANG, C., LING, T., LIU, R., ZONG, L., GUAN, Y., HUANG, X., SUN, L., ZHANG, L., LI, C. et al., (2018). Genome and epigenome analysis of monozygotic twins discordant for congenital heart disease. BMC Genomics 19: 428.

MACHADO, S.A., REICHENBACH, H.D., WEPPERT, M., WOLF, E. and GONCALVES, P.B. (2006). The variability of ovum pick-up response and in vitro embryo production from monozygotic twin cows. Theriogenology 65: 573-583.

MANCILL, S.S., BLODGETT, G., ARNOTT, R.J., ALVARENGA, M., LOVE, C.C. and HINRICHS, K. (2011). Description and genetic analysis of three sets of monozygotic twins resulting from transfers of single embryos to recipient mares. J Am Vet Med Assoc 238: 1040-1043.

MCLAREN, A., MOLLAND, P. and SIGNER, E. (1995). Does monozygotic twinning occur in mice? Genet Res 66: 195-202.

MCNULTY, N.P., YATSUNENKO, T., HSIAO, A., FAITH, J.J., MUEGGE, B.D., GOODMAN, A.L., HENRISSAT, B., OOZEER, R., COOLS-PORTIER, S., GOBERT, G. et al., (2011). The impact of a consortium of fermented milk strains on the gut microbiome of gnotobiotic mice and monozygotic twins. SciTrans/Med3: 106ra106.

MITALIPOV, S.M., YEOMAN, R.R., KUO, H.C. and WOLF, D.P. (2002). Monozygotic twinning in rhesus monkeys by manipulation of in vitro-derived embryos. Bio Reprod 66: 1449-1455.

MOOR, R.M. and TROUNSON, A.O. (1977). Hormonal and follicular factors affecting maturation of sheep oocytes in vitro and their subsequent developmental capacity. $J$ Reprod Fertil 49: 101-109.

MOORE, N.W., ADAMS, C.E. and ROWSON, L.E. (1968). Developmental potential of single blastomeres of the rabbit egg. J Reprod Fertil 17: 527-531.

MORRIS, S.A., GUO, Y. and ZERNICKA-GOETZ, M. (2012). Developmental plasticity is bound by pluripotency and the Fgf and Wnt signaling pathways. Cell Rep 2: 756-765.

MOUSTAFA, L. and HAHN, J. (1978). Experimentelle Erzeugung von identischen Mäusezwillingen. Dtsch. Tierärztl. Wochenschr. 85: 242-244.

MULLEN, R.J., WHITTEN, W.K. and CARTER, S.C. (1970). Studies of chimeric mice and half embryos. In: Ann. Rep. Jackson Lab. 67-68.

MUSTAFA, F., NAJAM, Y., AKBAR, M.T. and AHMED, T.A. (2017). Discordant disease expression of neonatal lupus erythematosus in twins. JPakMedAssoc67:939-941.

NAGASHIMA, H., KATO, Y. and OGAWA, S. (1989). Microsurgical bisection of porcine morulae and blastocysts to produce monozygotic twin pregnancy. Gamete Res 23: 1-9.

NAGATOMO, H., YAO, T., ARAKI, Y., MIZUTANI, E. and WAKAYAMA, T. (2017), Agarose capsules as new tools for protecting denuded mouse oocytes/embryos during handling and freezing-thawing and supporting embryonic development in vivo. Sci Rep 7: 17960.

NICHOLAS, J.S. and HALL, B.V. (1942). Experiments on developing rats. II. The development of isolated blastomeres and fused eggs. J Exp Zool 90: 441-459.

NIEMANN, H. (1985). Freezing of bovine embryos: effects of a one-step addition of 
1.4 M glycerol. Theriogenology 23: 369-379.

NIEMANN, H. and SACHER, B. (1984). [Monozygotic twins following the nonsurgical transfer of a deep-frozen and rethawed bovine embryo]. Dtsch Tierarztl Wochenschr 91: 266-267.

NOLI, L., DAJANI, Y., CAPALBO, A., BVUMBE, J., RIENZI, L., UBALDI, F.M., OGILVIE, C., KHALAF, Y. and ILIC, D. (2015). Developmental clock compromises human twin model created by embryo splitting. Hum Reprod 30: 2774-2784.

NOLI, L., OGILVIE, C., KHALAF, Y. and ILIC, D. (2017). Potential of human twin embryos generated by embryo splitting in assisted reproduction and research. Hum Reprod Update 23: 156-165.

NORMAN, H.D., LAWLOR, T.J., WRIGHT, J.R. and POWELL, R.L. (2004). Performance of Holstein clones in the United States. J Dairy Sci 87: 729-738.

NOWSHARI, M.A. and HOLTZ, W. (1993). Transfer of split goat embryos without zonae pellucidae either fresh or after freezing. J Anim Sci 71: 3403-3408.

OKUMURA, T., SAITO, K., SAKUMA, H., NADE, T., NAKAYAMA, S., FUJITA, K. and KAWAMURA, T. (2007). Intramuscular fat deposition in principal muscles from twenty-four to thirty months of age using identical twins of Japanese Black steers. J Anim Sci 85: 1902-1907.

OLIVIERI, F., AHTIAINEN, M., LAZZARINI, R., POLLANEN, E., CAPRI, M., LORENZI, M., FULGENZI, G., ALBERTINI, M.C., SALVIOLI, S., ALEN, M.J. et al., (2014). Hormone replacement therapy enhances IGF-1 signaling in skeletal muscle by diminishing miR-182 and miR-223 expressions: a study on postmenopausal monozygotic twin pairs. Aging Cell 13: 850-861.

OZIL, J.P. (1983). Production of identical twins by bisection of blastocysts in the cow. $J$ Reprod Fertil 69: 463-468.

OZIL, J.P., HEYMAN, Y. and RENARD, J.P. (1982). Production of monozygotic twins by micromanipulation and cervical transfer in the cow. Vet Rec 110: 126-127.

PAPAIOANNOU, V.E., MKANDAWIRE, J. and BIGGERS, J.D. (1989). Development and phenotypic variability of genetically identical half mouse embryos. Development 106: 817-827.

RAHMAN, A.N.M.A., ABDULLAH, R.B. and WAN-KHADIJAH, W.E. (2008). Gametogenesis, fertilization and early embryogenesis in mammals with special reference to goat: A review. J Biol Sci 8: 1115-1128.

ROBERTS, M.A., LONDON, K., CAMPOS-CHILLON, L.F. and ALTERMATT, J.L. (2015). Presumed monozygotic twins develop following transfer of an in vitroproduced equine embryo. J Equine Sci 26: 89-94.

ROBERTS, R.M., KATAYAMA, M., MAGNUSON, S.R., FALDUTO, M.T. and TORRES, K.E. (2011). Transcript profiling of individual twin blastomeres derived by splitting two-cell stage murine embryos. Biol Reprod 84: 487-494.

ROSSANT, J. (1976). Postimplantation development of blastomeres isolated from 4- and 8-cell mouse eggs. J Embryol Exp Morphol 36: 283-290.

ROWSON, L.E. and MOOR, R.M. (1964). Occurrence and Development of Identical Twins in Sheep. Nature 201: 521.

ROWSON, L.E. and MOOR, R.M. (1966). Embryo transfer in the sheep: the significance of synchronizing oestrus in the donor and recipient animal. $J$ Reprod Fertil 11: 207-212.

RUNNER, M.N. (1984). New evidence for monozygotic twins in the mouse: twinning initiated in the late blastocyst can account for mirror image asymmetries. Anat Rec 209: 399-406.

SCHRAMM, R.D. and PAPROCKI, A.M. (2004). Strategies for the production of genetically identical monkeys by embryo splitting. Reprod Biol Endocrinol 2: 38.

SEIDEL, F. (1952). Die Entwicklungspotenzen einer isolierten Blastomere des Zweizellenstadiums Im Säugetierei. Naturwissenschaften 39: 353-356.

SEIDEL, F. (1960). Die Entwicklungsfähigkeiten isolierter Furchungszellen aus dem Ei des Kaninchens Oryctolagus cuniculus. Wilhelm Roux Arch Entwickl Mech Org 152: 43-130.

SEIKE, N., SAKAI, M. and KANAGAWA, H. (1991). Development of frozen-thawed demi-embryos and production of identical twin calves of different ages. $J$ Vet Med Sci 53: 37-42.

SEIKE, N., TERANISHI, M., YAMADA, S., TAKAKURA, R., NAGAO, Y. and KANAGAWA, H. (1989). Increase in calf production by the transfer of bisected bovine embryos. Nihon Juigaku Zasshi 51: 1193-1199.

SILBER, S.J., LENAHAN, K.M., LEVINE, D.J., PINEDA, J.A., GORMAN, K.S., FRIEZ, M.J., CRAWFORD, E.C. and GOSDEN, R.G. (2005). Ovarian transplantation between monozygotic twins discordant for premature ovarian failure. $N$ Engl $J$
Med 353: 58-63.

SOTOMARU, Y., KATO, Y. and TSUNODA, Y. (1998). Production of monozygotic twins after freezing and thawing of bisected mouse embryos. Cryobiol. 37: 139-145.

SUZUKI, T., SAKAI, Y., ISHIDA, T. and KANOUCHI, T. (1991). Production of identical twins from bovine embryos split pre- or post-freezing. Jpn J Anim Reprod 37: $237-242$

SZELL, A. and HUDSON, R.H. (1991). Factors affecting the survival of bisected sheep embryos in vivo. Theriogenology 36: 379-387.

TAGAWA, M., MATOBA, S., NARITA, M., SAITO, N., NAGAI, T. and IMAI, K. (2008). Production of monozygotic twin calves using the blastomere separation technique and Well of the Well culture system. Theriogenology 69: 574-582.

TANG, F., BARBACIORU, C., NORDMAN, E., BAO, S., LEE, C., WANG, X., TUCH B.B., HEARD, E., LAO, K. and SURANI, M.A. (2011). Deterministic and stochastic allele specific gene expression in single mouse blastomeres. Plos One 6: e21208.

TANG, H.H., TSAI, Y.C. and KUO, C.T. (2012). Embryo splitting can increase the quantity but not the quality of blastocysts. Taiwan J Obstet Gynecol 51: 236-239.

TARKOWSKI, A.K. (1959a). Experimental studies on regulation in the development of isolated blastomeres of mouse eggs. Acta Theriol 3: 191-267.

TARKOWSKI, A.K. (1959b). Experiments on the development of isolated blastomers of mouse eggs. Nature 184: 1286-1287.

TARKOWSKI, A.K., OZDZENSKI, W. and CZOLOWSKA, R. (2001). Mouse singletons and twins developed from isolated diploid blastomeres supported with tetraploid blastomeres. Int J Dev Biol 45: 591-596.

TARKOWSKI, A.K., OZDZENSKI, W. and CZOLOWSKA, R. (2005). Identical triplets and twins developed from isolated blastomeres of 8- and 16-cell mouse embryos supported with tetraploid blastomeres. Int J Dev Biol 49: 825-832.

TARKOWSKI, A.K. and WROBLEWSKA, J. (1967). Development of blastomeres of mouse eggs isolated at the 4- and 8-cell stage. JEmbryol Exp Morphol18: 155-180.

TSUNODA, Y. and MCLAREN, A. (1983). Effect of various procedures on the viability of mouse embryos containing half the normal number of blastomeres. $J$ Reprod Fertil 69: 315-322.

TSUNODA, Y., TOKUNAGA, T., SUGIE, T. and KATSUMATA, M. (1985). Production of monozygotic twins following the transfer of bisected embryos in the goats. Theriogenology 24: 337-343.

UDY, G.B. (1987). Commercial splitting of goat embryos. Theriogenology 28: 837-847.

USHIJIMA, H. (2005). Application study of developmental engineering for livestock production. J Reprod Dev 51: 15-22.

VAJTA, G., PEURA, T.T., HOLM, P., PALDI, A., GREVE, T., TROUNSON, A.O. and CALLESEN, H. (2000). New method for culture of zona-included or zona-free embryos: the Well of the Well (WOW) system. Mol Reprod Dev 55: 256-264.

VALER CARSTEA, B., CATUNDA LEMOS, A.P., ILIE, E.D., VARGA, L., BODO, S., KOVACS, A., BOSZE, Z. and GOCZA, E. (2007). Production of identical mouse twins and a triplet with predicted gender. Cloning Stem Cells 9: 247-256.

VANDE VELDE, H., CAUFFMAN, G., TOURNAYE, H., DEVROEY, P. and LIEBAERS, I. (2008). The four blastomeres of a 4-cell stage human embryo are able to develop individually into blastocysts with inner cell mass and trophectoderm. Hum Reprod 23: 1742-1747.

VENCOVSKY, J., MAGEED, R.A., OLLIER, W.E. and MAINI, R.N. (1995). Monozygotic rheumatoid arthritis twin pairs express similar levels of conserved immunoglobulin $\checkmark$ gene in polyclonal rheumatoid factors irrespective of disease status. Scand $J$ Immunol 42: 147-157.

VERMILYEA, M.D., MANECK, M., YOSHIDA, N., BLOCHBERGER, I., SUZUKI, E., SUZUKI, T., SPANG, R., KLEIN, C.A. and PERRY, A.C. (2011). Transcriptome asymmetry within mouse zygotes but not between early embryonic sister blastomeres. EMBO J 30: 1841-1851.

VINOGRAD, C.A., SRIVASTAVA, S. and PANESAR, L.E. (2013). Fetal diagnosis of left-ventricular noncompaction cardiomyopathy in identical twins with discordant congenital heart disease. Pediatr Cardiol 34: 1503-1507.

WALLACE, M.E. and WILLIAMS, D.A. (1965). Monozygotic twinning in mice. J Med Genet 2: 26-31.

WANG, Z.J., TROUNSON, A. and DZIADEK, M. (1990). Developmental capacity of mechanically bisected mouse morulae and blastocysts. Reprod Fertil Dev 2: 683-691.

WARFIELD, S., SEIDEL, G. and ELSDEN, R. (1986). Transfer of bovine demi-embryos with and without zonae pellucidae. Theriogenology 25: 212. 
WATANABE, Y., NONAKA, K., SASAKI, Y. and NAKATA, M. (1998). A longitudinal observation of the postnatal craniofacial growth in artificial monozygotic twin mice. $J$ Craniofac Genet Dev Biol 18: 107-118.

WILLADSEN, S.M. (1979). A method for culture of micromanipulated sheep embryos and its use to produce monozygotic twins. Nature 277: 298-300.

WILLADSEN, S.M. (1981). The development capacity of blastomeres from 4- and 8-cell sheep embryos. J Embryol Exp Morphol 65: 165-172.

WILLADSEN, S.M. and GODKE, R.A. (1984). A simple procedure for the production of identical sheep twins. Vet Rec 114: 240-243.

WILLADSEN, S.M. and POLGE, C. (1981). Attempts to produce monozygotic qua- druplets in cattle by blastomere separation. Vet Rec 108: 211-213.

WILLIAMS, T.J., ELSDEN, R.P. and SEIDEL, G.E., JR. (1984). Pregnancy rates with bisected bovine embryos. Theriogenology 22: 521-531.

WILLIAMS, T.J. and MOORE, L. (1988). Quick-splitting of bovine embryos. Theriogenology 29: 477-484.

WOOD, E.C. and TROUNSON, A. (2000). Uses of embryo duplication in humans: embryology and ethics. Hum Reprod 15: 497-501.

WU, H., ZENG, B., LI, B., REN, B., ZHAO, J., LI, M., PENG, X., FENG, M., LI, J., WEI, H. et al., (2018). Research on oral microbiota of monozygotic twins with discordant caries experience - in vitro and in vivo study. Sci Rep 8: 7267. 


\section{Further Related Reading, published previously in the Int. J. Dev. Biol.}

Mammalian Embryology Conference: celebrating the pioneering work of Andrzej K. Tarkowski (Warsaw, Poland, 25-26 October, 2013) Magdalena Krupa, Aneta Suwińska and Marek Maleszewski

Int. J. Dev. Biol. (2013) 57: 799-808

https://doi.org/10.1387/ijdb.130321mm

Early mammalian embryo: my love. An interview with Andrzej K. Tarkowski

Marek Maleszewski and Andrzej K. Tarkowski

Int. J. Dev. Biol. (2008) 52: 163-169

https://doi.org/10.1387/ijdb.072377mm

Mouse chimaeras developed from electrofused blastocysts: new evidence for developmental plasticity of the inner cell mass Andrzej K. Tarkowski, Kamila Jagiello, Renata Czolowska and Waclaw Ozdzenski Int. J. Dev. Biol. (2005) 49: 909-914

http://www.intjdevbiol.com/web/paper/052017at

Identical triplets and twins developed from isolated blastomeres of 8-and 16-cell mouse embryos supported with tetraploid blastomeres

Andrzej K. Tarkowski, Waclaw Ozdzenski and Renata Czolowska

Int. J. Dev. Biol. (2005) 49: 825-832

http://www.intjdevbiol.com/web/paper/052018at

Polyembryony in parasitic wasps: evolution of a novel mode of development.

Grbic M.

Int J Dev Biol. 2003;47(7-8):633-42.

Mouse singletons and twins developed from isolated diploid blastomeres supported with tetraploid blastomeres

A K Tarkowski, W Ozdzenski and R Czolowska

Int. J. Dev. Biol. (2001) 45: 591-596

http://www.intjdevbiol.com/web/paper/11417903

A history of mammalian embryological research

H Alexandre

Int. J. Dev. Biol. (2001) 45: 457-467

http://www.intjdevbiol.com/web/paper/11417885
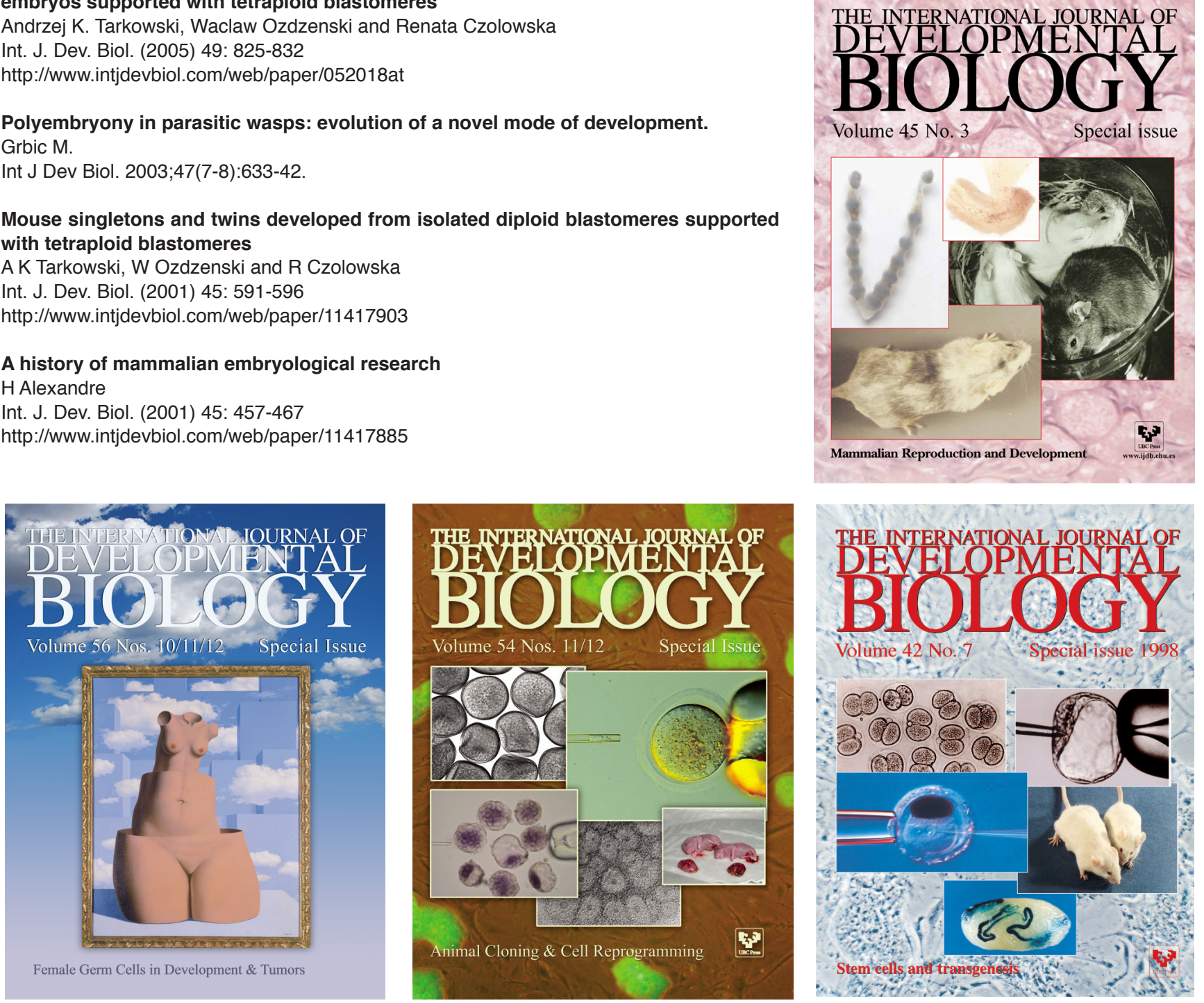